\title{
TINJAUAN HUKUM PERLINDUNGAN SAKSI DAN KORBAN DALAM IMPLEMENTASI UU No. 13 TAHUN 2006
}

Oleh :

Ojaruddin, SH, MH.

\section{LATAR BELAKANG}

Keberhasilan sebuah proses peradilan pidana pada dasarnya tidak terlepas dari peran "Alat Bukti" yang berhasil diungkap atau ditemukan, padahal fakta dalam proses persidangan umumnya banyak kasus yang tidak terungkap berkenaan dengan saksi, dan alat bukti yang tidak mendukung. Bahwa permasalahan ini semata - mata terjadi karena dalam pelaksanaan dilapangan belum jelas pelaksanaan perlindungan bagi mereka yang menjadi saksi sehingga menyebabkan saksi dan korban takut memberikan kesaksian.

Dalam masalah penegakan hukum (law enforcement) terdapat kehendak agar hukum tegak, sehingga nilai- nilai yang diperjuangkan melalui instrumen hukum yang bersangkutan dapat diwujudkan. Sedangkan dalam menggunakan hukum, cita- cita yang terkandung dalam hukum belum tentu secara sungguh - sungguh hendak diraih, sebab hukum tersebut digunakan untuk membenarkan tindakantindakan yang dilakukan. ${ }^{1}$

Hal ini menurut Prof Ronny Nitibaskara (Kriminolog - UI) yang perlu diwaspadai adalah, umumnya dalam praktik penggunaan hukum juga melibatkan keahlian professional dalam bidang hukum, yang setelah keahlian ini berkolaborasi dengan keahlian lainnya berikut kekuasaan, maka hukum dapat dijadikan pembenar untuk tindak kekerasan, diskriminasi, dan bahkan untuk meraih berbagai keuntungan yang sebenarnya tidak sah ( korupsi). Dalam hal ini korupsi akan menjadi sempurna dengan menggunakan hukum, karena menjadi sulit untuk dilacak.

Praktik menggunakan hukum untuk mengukuhkan kepentingan, pada dasarnya terkait dengan budaya penguasa yang memerintah saat itu. Semakin halus

${ }^{1}$ Tb.Ronny R Nitibaskara: Tegakkan Hukum Gunakan Hukum; 2006 ;ix. 
budaya yang dianut penguasa, tetapi semakin totaliter biasanya hukum diangung- agungkan tapi tidak untuk ditegakkan. Akibatnya adalah terjadi berbagai diskriminasi karena hukum juga dapat digunakan sebagai alasan untuk melakukan berbagai tindak kekerasan, termasuk pelanggaran HAM berat, karena menganggap pelanggaran tersebut mempunyai dasar hukum. Jadi dalam hal ini perasaan bersalah dari pelaku kejahatan hilang, bahkan tidak peka sama sekali atas ketidak adilan yang dilakibatkan pemutar balikan fakta hukum.

Sering terjadi pada proses peradilan orang sungguh- sungguh berbicara tentang hukum, dan bahkan tampak sedemikian keras, akan tetapi mereka tidak sungguhsungguh berniat untuk menegakkan hukum. Jadi dalam hal ini menurut Prof. Rony Nitibaskara bahwa :"Menegakkan hukum tanpa menggunakan Hukum dapat melahirkan tindakan sewenangwenang, namun sebaliknya bila menggunakan Hukum tanpa berniat menegakkan hukum, dapat menimbulkan ketidak adilan bahkan dapat membawa keadaan menjadi seperti tanpa hukum" ${ }^{2}$. Dengan begitu lembaga yang bersentuhan dengan sistem peradilan pidana di Indonesia (Polisi, Jaksa, Hakim, Lawyer, Lembaga Pemasyarakatan), dan lembaga lainnya harus mewaspadai kondisi yang menantang ini.

Dalam catatan statistik Kepolisian ada dikenal istilah "Dark Number Crime" atau Angka Gelap Kejahatan. Disadari atau tidak oleh kalangan Kepolisian, kondisi ini sesungguhnya merupakan sesuatu yang harus dipecahkan, mengingat bukan tanpa sebab angka tersebut dapat muncul. Kemudian bila dikaji lebih jauh

${ }^{2}$ Ibid; xii. ternyata ada beberapa sebab angka gelap kejahatan tersebut muncul antara lain :

1. Ketidak tahuan orang akan prosesur penyelesaian kasus yang terjadi, akibatnya mereka lebih baik berdiam diri;

2. Adanya ancaman dari pihak- pihak tertentu bila kasus akan dilaporkan kepihak yang berwenang / polisi;

3. Ketakutan orang akan kemungkinan menjadi turut terlibat dalam suatu kasus / jadi saksi bila mereka melaporkan kejadian / perkara mengingat jadi saksi berarti beban waktu dan ekonomi buat mereka, akibatnya mereka menjadi tidak perduli;

4. Kecenderungan ada prosedur yang berbelit - belit dari pihak kepolisian sehingga orang bersikap lebih baik tidak usah melapor;

5. Ada faktor Dominasi didalam rumah tangga bila kejahatan berkaitan dengan kasus - kasus Kekerasan Dalam Rumah Tangga;

6. Bila berkaitan dengan Corporate Crime, ada kesulitan bagi mereka untuk melapor, mengingat melaporkan suatu tindak pidana dalam birokrasi berarti beresiko pada pribadi, dan orang lainnya.

Oleh karena itu dalam rangka menumbuhkan partisipasi masyarakat untuk mengungkap suatu tindak pidana, perlu diciptakan situasi yang kondusif, yaitu dengan cara memberikan perlindungan hukum dan jaminan keamanan kepada setiap orang yang mengetahui atau menemukan hal- hal yang dapat membantu pengungkapan tindak pidana yang telah terjadi dan melaporkan hal tersebut kepada institusi yang berwenang. 
Berkaitan dengan Hak Asasi Manusia, perlindungan saksi dan korban dalam proses peradilan pidana di Indonesia memang belum diatur secara khusus dalam UU No. 8 tahun 1981 (KUHAP), mengingat yang diperhatikan dalam undang- undang ini tepatnya pada pasal 50 KUHAP sampai dengan pasal 68 KUHAP hanya mengatur perlindungan terhadap tersangka atau terdakwa. Oleh karena itu berdasarkan atas azas kesamaan didepan hukum (equality before the law) sebagai salah satu ciri Negara hukum, saksi dan korban dalam proses peradilan pidana harus diberi perlindungan hukum yang dituangkan dalam beberapa Peraturan Pemerintah antara lain :

1. Peraturan Pemerintah No 2 tahun 2002 tentang Tata Cara Perlindungan Saksi dalam perkara pelanggaran berat Hak Asasi Manusia;

2. Peraturan Pemerintah No. 3 tahun 2002 tentang Kompensasi, Restitusi dan Rehabilitasi terhadap korban pelanggaran berat HAM;

3. Peraturan Pemerintah No. 24 tahun 2003 tentang Tata Cara Perlindungan Terhadap Saksi, Penuntut Umum dan Hakim dalam perkara Tindak Pidana Terorisme;

4. Peraturan Pemerintah No. 57 tahun 2003 tentang Tata Cara Perlindungan khusus bagi Pelapor dan Saksi Tindak Pidana Pencucian Uang;

Sejalan dengan perkembangan kesadaran akan perlunya perlindungan saksi dan korban secara lebih luas yang artinya tidak terbatas pada jenis tindak pidana tertentu saja maka diterbitkan UU No 13 tahun 2006 tentang Perlindungan Saksi dan Korban (PSK) dan salah satu pokok materi muatan dalam undang- undang itu adalah terbentuknya sebuah Lembaga Perlindungan Saksi dan Korban (LPSK ).
Namun demikian berdasarkan pasal 44 UU No. 13 tahun 2006 masih menjelaskan bahwa peraturan yang mengatur tentang perlindungan saksi / korban masih tetap berlaku sepanjang tidak bertentangan dengan undang- undang ini.

Penanganan terhadap saksi dan korban yang diberikan LPSK baik dalam bentuk perlindungan, bantuan serta pemberian restitusi dan kompensasi adalah wujud dari layanan yang diberikan LPSK sesuai dengan amanat UU, dan pemberian perlindungan dan bantuan tersebut dapat diberikan atau difasilitasi oleh LPSK dengan melihat berbagai aspek yang antara lain menurut Pasal 28 UU Perlindungan Saksi dan Korban adalah sifat pentingnya keterangan saksi dan korban, tingkat ancaman yang membahayakan saksi dan korban, Hasil analisa tim medis atau psikolog terhadap saksi dan korban serta rekam jejak kejahatan yang pernah dilakukan saksi dan korban

Lembaga Perlindungan Saksi dan Korban (LPSK) sebagaimana dinyatakan dalam pasal 11 ayat (1) adalah merupakan lembaga yang Mandiri, bertanggung jawab untuk menangani pemberian perlindungan dan bantuan pada Saksi dan Korban berdasarkan tugas dan kewenangan sebagaimana diatur dalam undangundang ini. Pasal 12 undang-undang PSK selanjutnya yang dimaksudkan dengan "Lembaga yang Mandiri" dalam hal ini adalah sebagai lembaga yang independen, tanpa campurtangan dari pihak manapun.

Sebagaimana telah dialami oleh LPSK dalam upaya pembentukannya ternyata telah mengalami berbagai macam tantangan, termasuk didalamnya adalah tuduhan pada pemerintah yang tidak bersungguh - sungguh untuk mengimplementasikan terbentuknya 
LPSK. Kondisi ini tidak mungkin disembunyikan mengingat begitu banyak permasalahan Negara yang harus diprioritaskan di Negara ini. Kecurigaan, sinisme, skeptisisme akan bentukan lembaga baru ini menjadikan LPSK seakan- akan tidak perlu dibentuk. Oleh karena itu bukan hal yang mudah bagi LPSK dalam proses operasional kedepan, namun demikian memang perlu harus tetap optimis mengingat pentingnya proses peradilan yang bersih dan berwibawa demi menegakkan hukum di Negara kita.

\section{SAKSI DAN KORBAN}

Saksi adalah mereka yang mempunyai pengetahuan sendiri berdasarkan apa yang dialaminya, dilihatnya, dan atau didengarnya berkenaan dengan dugaan terjadinya suatu tindak pidana (Pasal 1 angka 26 KUHAP). Berdasarkan definisi tersebut sangat mungkin bahwa saksi akan berstatus juga sebagai korban, dalam arti memang dia juga yang dirugikan oleh perbuatan pidana tersebut. Bahwa saksi diharapkan dapat menjelaskan rangkaian kejadian yang berkaitan dengan sebuah peristiwa yang menjadi obyek pemeriksaan di muka sidang pengadilan. Dengan begitu saksi bersama dengan alat bukti yang lain akan membantu hakim dalam penjatuhan putusan yang obyektif berdasarkan faktafakta hukum yang ada.

Dalam sebuah proses peradilan pidana, saksi adalah kunci yang menentukan untuk memperoleh kebenaran materil. Hal ini dikemukakan dalam pasal $184-185$ UU No. 8 / 1981 tentang Hukum Acara Pidana (KUHAP) yang menjelaskan bahwa (pasal 184) menempatkan keterangan saksi diurutan pertama diatas alat bukti lain berupa keterangan ahli, surat, petunjuk, dan keterangan terdakwa.
Pasal 185 (2) menyatakan bahwa : "Keterangan seorang saksi saja tidak cukup untuk membuktikan bahwa terdakwa bersalah terhadap perbuatan yang didakwakan kepadanya". Dan Pasal 185 (3) menjelaskan bahwa :"Ketentuan sebagaimana dimaksud dalam ayat (2) tidak berlaku apabila tidak disertai alat bukti yang sah lainnya". Dengan demikian keterangan dari satu orang saksi saja tanpa disertai alat bukti lainnya, dianggap tidak cukup untuk membuktikan apakah seseorang terdakwa itu bersalah atau tidak.

Berkaitan dengan perlindungan saksi dan korban, hal ini dapat dilihat pada saat persidangan mengupayakan pengambilan keterangan saksi. Bahwa saksi harus dapat memberikan keterangan yang sebenarbenarnya, untuk itu saksi memerlukan situasi yang aman sebagaimana dinyatakan dalam pasal 173 KUHAP yang memberikan kemungkianan seorang saksi bersaksi tanpa kehadiran terdakwa. Hal ini dimaksudkan untuk mengakomodir kepentingan saksi agar ia dapat bersaksi lebih leluasa tanpa ada rasa takut ataupun tekanan dari terdakwa.

Dalam upaya pengumpulan keterangan saksi ternyata ada beberapa kendala yang mempengaruhi kondisi saksi untuk bersaksi seperti halnya seorang saksi mungkin saja menolak untuk bersaksi mengingat ada rasa takut untuk bersaksi sebab ancaman seseorang, dan ancaman tersebut bisa saja diarahkan kepada dirinya ataupun keluarganya. Hal lain adalah saksi masih dalam kondisi trauma akibat peristiwa pidana yang dialaminya, sehingga yang bersangkutan tidak mampu untuk bersaksi secara penuh. Maka dengan demikian perlindungan saksi amat diperlukan untuk mendukung situasi kondusif bagi saksi yang akan bersaksi. 
Memperhatikan UU Perlindungan Saksi dan korban, bahwa Saksi dan Korban disini tidak secara tegas dijelaskan ada pemisahan antara Saksi dan Korban, karena fakta yang terjadi dilapangan "Korban memiliki dua status", yaitu Korban sebagai korban tindak pidana dan Korban sebagai Saksi yang dapat memberikan keterangan yang pengaturan pengertiannya sebagai berikut:

1. Saksi merupakan seorang yang seharusnya memberikan keterangan mengenai suatu peristiwa melalui kesaksiannya didepan hakim. Nilai pembuktian dari kesaksian Saksi dalam penuntutan pelaku pidana dibidang kejahatan bukan hanya bersifat penting, tapi juga satu- satunya alat pembuktian yang tidak dapat diabaikan;

2. Saksi Korban adalah merupakan seorang Saksi yang pada saat bersamaan merupakan korban dari suatu tindak pidana. Untuk saksi Korban dalam hal ini diberikan hak "Nebenklage" (pasal 395 KUHAP) dan "Adhasionsverfahren" (pasal 403 KUHAP), maupun hak mendapatkan Pengacara (pasal 406 KHUAP);

3. Saksi Secara Kebetulan adalah orang yang telah melihat suatu tindak pidana karena secara kebetulan mereka berada pada waktu dan tempat tindak pidana dilakukan;

4. Saksi sebagai Pelaku adalah mereka yang merupakan bagian suatu kelompok pelaku tindak pidana dan kemudian keluar dari kelompok tersebut dan melaporkan kepada polisi. Mereka umumnya mempunyai informasi dari kelompok yang telah ditinggalkan.
Berkaitan dengan Korban, sebagaimana telah diungkapkan diatas, dalam banyak hal umumnya korban enggan berurusan dengan penegak hukum karena pertimbangan kemungkinan tidak akan mengurangi penderitaannya, bahkan mungkin akan memperparah kondisinya sendiri, seperti halnya korban harus mengingat - ingat kembali hal- hal yang menyakitkan untuk diceritakan kepada pihak yang menerima laporan.

Selain itu bisa jadi Korban justru menjadi obyek cemo'ohan/pelecehan petugas yang menerima laporan bila kasusnya berkaitan dengan kasus perzinahan, perselingkuhan, pelecehan seksual, Feudufelia dan lainnya. Dalam hal ini Korban adalah mereka yang mengalami penderitaan atau kesakitan, baik fisik maupun mental sebagai akibat dari tindakan orang lain, kelompok atau lembaga yang secara semena- mena malakukan perbuatan atas kepentingannya melanggar hak orang lain. Untuk itu korban dapat digolongkan dalam beberapa tipe antara lain ${ }^{3}$ :

1. Korban yang tidak taumenahu, tapi menjadi korban karena kesalahan memang ada pada pelaku kejahatan;

2. Korban yang secara sadar atau tidak ternyata turut serta mendukung untuk pelaku melakukan perbuatan jahat. Jadi dalam hal ini korban turut andil dalam perbuatan jahat yang dilakukan oleh pelaku.

3. Korban yang secara biologis memang potensi untuk menjadi korban, seperti anak- anak, perempun, Manula dan lainnya;

4. Korban yang pelakunya adalah diri sendiri seperti halnya pelacuran, perzinahan Bunuh diri dan lainnya.

\footnotetext{
${ }^{3}$ Made Darma Weda SH, MS; Kriminologi; Jakarta ;90
} 
Maraknya kejahatan dengan model kejahatan Kontemporer dimana pelakupelaku kejahatan tersebut umumnya kaum intelektual, dengan didukung oleh perangkat berteknologi tinggi, serta memiliki jaringan secara internasional, ternyata menghasilkan korban kejahatan yang tidak sedikit.

Saksi dalam hal ini akan mengalami kesulitan untuk bersaksi mengingat posisi mereka yang secara tidak langsung juga berada pada jaringan tersebut. Dilema yang dihadapi oleh saksi dalam situasi ini membuat sebuah kasus pidana menjadi sulit terungkap. Bahkan dengan berbagai dalih dan kemampuan yang dimiliki oleh kaum intelektual ini, mereka justru dapat memanfaatkan legalitas formal aturan yang ada untuk dijadikan pelindung semua perbuatan yang dilakukannya. Dalam hal ini masalah penegakan hukum adalah faktor utama yang perlu mendapat perhatian mengingat indikasi pelanggaran hak asasi sesama manusia yang dilakukan oleh kaum intelektual atas kepentingan mereka.

\section{BEBERAPA KASUS YANG SEGERA MEMERLUKAN UU NO 13 / 2006}

Sebagaimana latar belakang pertimbangan perlu dibentuknya UU No. 13 tahun 2006 tentang Perlindungan Saksi dan Korban, termasuk didalamnya implementasi kerja LPSK, yaitu bahwa penting untuk bisa mendapatkan alat bukti yang sah dalam proses peradilan pidana. Dan alat bukti yang sah tersebut secara fakta antara lain dapat diperoleh melalui keterangan Saksi dan atau Korban yang mendengar, melihat, atau mengalami sendiri terjadinya suatu tindak pidana. Hal ini diperlukan untuk mencari dan menemukan kejelasan tentang tindak pidana yang dilakukan olen pelakunya. Untuk itu ada beberapa kasus yang dapat dikemukakakan berkaitan dengan perlunya segera implementasi UU No. 13 / 2006 antara lain :

1. Kasus yang berkaitan dengan pelanggara hak Sipil dan Politik, sejalan dengan telah di ratifikasinya International Covenant on Civil and Political Rights, 1966 (Kovenan Internasional tentang Hak-Hak Sipil dan Politik yang sudah disyahkan dengan UU No. 12 / 2005, tanggal 28 Oktober 2005 dan International Covenant on Economic, Social dan Cultural Rights, 1966 (Kovenan Internasional tentang Hak-Hak Ekonomi, Sosial dan Budaya yang sudah disyahkan dengan UU No. 11/2005, tanggal 28 Oktober 2005), ternyata kondisi yang ada di Negara ini masih terjadi pelanggranpelanggaran hak asasi manusia seperti halnya permasalahan yang berkaitan dengan Agama dan kepercayaan, Penyiksaan orang yang dilakukan oleh kelompok tertentu, rakyat yang tidak berdaya atas eksistensinya dan lainnya. Dalam kasus- kasus saksi korban akan mengalami banyak kesulitan untuk berekpresi menyampaikan apa yang dialami dan dilihatnya tanpa didukung oleh perlindungan yang secara legalitas sah dan jelas, mengingat kemungkinan lawan ataupun musuh mereka tidak bisa diremehkan dalam hal ancaman ataupun perlawanan yang bisa berakibat fatal bagi siapa saja yang berani bersaksi.

2. Kasus kasus yang berkaitan dengan mafia tanah, umumnya pelanggaran hak asasi manusia amat rentan diwilayah ini. Dengan dalih penggusuran untuk "kepentingan umum" disini tanah rakyat di gusur secara semena- mena tanpa ada 
kejelasan masalah penggantiannya. Tata cara penggusuran dengan menggunakan kekerasan membuat rakyat yang tidak berdaya harus bisa menerima tanpa perlawanan. Maka amat jelas disini bahwa pelanggaran HAM nyata terjadi terhadap mereka yang benar- benar tidak berdaya secara sosial maupun ekonomi. Oleh karena itu tanpa penjelasan yang lebih jauh, kondisi ini jelas sudah sangat memerlu ada pelindungan saksi dan korban.

3. Beberapa permasalahan Buruh yang sering kita saksikan dimedia elektronik maupun media umum lainnya, dimana kaum buruh sudah menyatakan secara jelas dengan bebagai argument, bahkan kaum buruh melakukan demo besarbesaran untuk menuntut keadilan atas diterbitkannya undang- undang ketenaga kerjaan yang tidak berpihak kepada kaum buruh. Dalam kondsi ini yang sering terjadi adalah justru para tokoh buruh yang dianggap vokal ditangkap dan diperlakukan secara tidak adil. Pada dasarnya dalam ketidak berdayaan mereka sebagai buruh dan kepentingan perjuangan mereka kaum buruh selayaknya perlu mendapatkan perlindungan dalam menyampaikan aspirasinya karena mereka merupakan korban kebijakan yang dibuat oleh pejabat publik atas kepentingan kelompok tertentu, yang berakibat pelanggaran hak asasi manusia atas hak- hak mendasar bagi kaum buruh.

\section{PERAN LEMBAGA PERLINDUNGAN SAKSI DAN KORBAN.}

Berdasarkan pasal 1 (butir 3) UU No 13 tahun 2006, Lembaga Perlindungan Saksi dan Korban (LPSK) adalah merupakan lembaga yang bertugas dan berwenang untuk memberikan perlindungan dan hakhak lain kepada saksi atau korban sebagaimana diatur dalam undangundang tersebut. Dan selanjutnya pada pasal 4 UU No 13/2006 ini menjelaskan bahwa perlindungan Saksi dan Korban bertujuan untuk memberikan rasa aman kepada saksi/korban ketika yang bersangkutan harus menyampaikan keterangan pada suatu proses peradilan pidana. Oleh karena itu ada beberapa hal khusus berkaitan dengan undang- undang ini yang dapat dikemukakan antara lain menyangkut :

1. Asas Perlindungan, bahwa pada dasarnya secara sosiologis undangundang No. 13 tahun 2006 tentang Perlindungan Saksi dan Korban dibuat karena adanya tuntutan dari masyarakat agar undang- undang ini dapat dijadikan tempat berlindung bagi mereka yang kebetulan harus menjadi saksi dalam suatu perkara tindak pidana, mengingat ada kemungkinan beresiko bagi mereka yang harus bersaksi. Hal ini dinyatakan dalam pasal 3 UU No 13/2006 sebagai beberapa asas perlindungan yaitu Penghargaan atas Harkat dan Martabat manusia, Pemberian Rasa Aman, Rasa Keadilan, Tidak Diskriminatif, dan Kepastian Hukum.

2. Aspek menejemen Organisasi Lembaga Perlindungan dan Saksi dalam hal ini dapat ditinjau dari dua aspek yaitu aspek Internal dan Eksternal. Sebagaimana dinyatakan dalam pasal 18 UU No 13/2006, dalam pelaksanaan tugasnya secara menejerial internal ada tujuh orang angggota LPSK dan dibantu oleh sebuah sekretariat yang memberikan 
pelayanan administrasi untuk menunjang aktivitas kerja LPSK. Selanjutnaya dalam kaitan menejemen ekternal sebagaimana dinyatakan dalam pasal 36 ayat ( 1 ) UU No 13/2006 bahwa dalam melaksanakan pemberian perlindungan dan bantuan, LPSK dapat bekerja sama dengan instansi terkait yang berwenang. Hal ini yang dimaksudkan adalah Lembaga pemerintah yang memang berada dalam sistem Peradilan pidana dan juga lembaga Non Pemerintah yang memiliki kapasitas dalam pemberian bantuan bagi Saksi dan korban. Oleh karena itu dari sisi menejemen eksternal memang diperlukan adanya suatu kesepakatan dan kesamaan dalam hal implementasi bentukbentuk perlindungan bagi Saksi dan Korban. Selanjutnya atas dasar pertimbangan tersebut sebagaimana tertuang dalam pasal 16 UU No 13 tahun 2006 ini, LPSK dalam menjalankan proses dan prosedur kerjanya tentu tidak terlepas dari aspek manajemen yang jelas, mandiri/independen, dan dipimpin oleh seorang ketua yang juga fleksibel dalam memimpin organisasi tersebut.

3. Kepatutan Anggota LPSK, dalam hal ini sebagaimana dinyatakan dalam pasal 23 ayat (2) huruf g, bahwa salah satu syarat untuk dapat diangkat menjadi anggota LPSK adalah memiliki Integritas dan kepribadian yang tidak tercela. Dan untuk memberhentikan seorang anggota LPSK sebagaimana dinyatakan dalam pasal 24 ( huruf e) adalah bila anggota tersebut melakukan perbuatan tercela. Dengan demikian reputasi yang baik bagi seorang anggota LPSK dapat dijadikan jaminan pelaksanaan kerja
LPSK dalam mengemban misi rahasia Negara

4. Memperhatikan pasal 11 ayat (2) UU No. 13 tahun 2006 yang menyatakan bahwa LPSK berkedudukan di Ibu kota Negara RI. Undang-Undang ini memang memprioritaskan kedudukan LPSK berada di Ibukota Negara Republik Indonesia, namun di samping berkedudukan di ibukota Negara dalam hal ini Jakarta, Undang-undang ini juga memberikan keluasan bagi LPSK untuk membentuk perwakilanya di wilayah atau daerah lain jika hal tersebut dianggap menjadi peran yang sangat penting untuk pemberian bantuan dan perlindungan.

\section{KESIMPULAN}

Hukum Pidana adalah merupakan hukum publik mengingat semua pelanggaran atas undang- undang akan berdampak pada masyarakat, dalam arti masyarakat yang akan dirugikan baik langsung maupun tidak langsung. Oleh karena itu Negara harus turut bertanggung jawab untuk mengatur dan melindung masyarakat baik mereka yang menjadi korban langsung, tidak langsung atau mereka yang harus berperan sebagai saksi. Dalam hal ini bentuk- bentuk perlindungan dapat di implementasikan antara lain dengan cara pemberian bantuan dalam bentuk Konsultasi, Pemberian Pendampingan, Bantuan Hukum, juga dalam bentuk Rehabilitasi fisik dan Psikhis. Pada dasarnya hal ini telah dinyatakan dalam pasal 5 dan pasal 6 UU No 13/2006. tentang Perlindungan Saksi dan Korban yang menjelaskan tentang hak - hak Korban.

Peran aktif LPSK amat dibutuhkan untuk mencapai seluruh wilayah Indonesia 
dalam penanganan saksi dan korban terutama yang berada di daerah luar Jakarta, namun kendala yang dihadapi LPSK dalam penanganan saksi dan korban di daerah lebih mengarah pada permasalahan dari luar LPSK yang antara lain :

1. Aspek geografis, mejadi kendala ketika LPSK memlakukan penanganan atas saksi dan korban yang berada di daerah wilayah yang sedikit sulit dijangkau (keterbatasan sarana dan prasarana daerah tersebut).

2. Kurangnya dukungan dari aparat penegak hukum yang berada diwilayah terkait dengan tugas dan fungsi LPSK dalam menjalankan mandat dari Undang-undang Nomor 13 Tahun 2006.

3. Keterkaitan terhadap kecepatan penanganan perkara dari aparat penegak hukum dan keterbatasan kewenangan dari LPSK berdasar undang-undang terkadang tidak sesuai dengan apa yang diinginkan saksi dan korban didaerah.

4. Pemahaman yang kurang terhadap hak-hak saksi dan korban oleh masyarakat di daerah maupun aparat penegak hukum itu sendiri menjadi sebuah permasalahan tersendiri bagi LPSK ketika memberikan perlindungan dan bantuan kepada saksi dan korban di daerah, hal ini dikarenakan keterbatasan informasi yang diperoleh di daerah dibandingkan dengan masyarakat dan aparat penegak hukum yang berada di Jakarta ataupun pulau jawa.

5. Pada dasarnya perlindungan dan bantuan bagi saksi dan korban di Indonesia yang diberikan Negara melalui LPSK sebagai pelaksanaan dari Undang-Undang Nomor 13 Tahun 2006, lebih difokuskan pada tindak pidana/kasus-kasus tertentu seperti penjelasan Pasal 5 ayat (2) yang dimaksud dengan "kasus-kasus tertentu", antara lain tindak pidana korupsi, tindak pidana narkotika / psikotropika, tindak pidana terorisme dan tindak pidana lain yang mengakibatkan posisi saksi dan korban dihadapkan pada situasi yang sangat membahayakan jiwanya.

6. Kenyataanya perlindugan dan bantuan bagi saksi dan korban saat ini bukan hanya diperlukan untuk tindak pidana atau kasus-kasus tertentu seperti dimaksud penjelasan Pasal 5 ayat (2) tersebut melainkan tindak pidana umum lainnya yang bersentuhan dengan konflik sosial di Indonesia terutama masyarakat $\mathrm{di}$ wilayah luar Jakarta dan luar pulau jawa yang sedikit lebih sensitif dengan permasalahan hukum yang dialami terlebih bila berada dalam posisi sebagai korban. Keberadaan LPSK sebagai lembaga yang memberikan penaganan terhadap hak-hak saksi dan korban diharapkan dapat menjadi bagian yang penting dan tak terpisahkan dari sistem peradilan pidana di indonesia.

\section{DAFTAR PUSTAKA}

1. Dr. Safoedin Bahar; Konteks Kenegaraan Hak Asasi Manusia; Pustaka Sinar Harapan; Jakarta 2002.

2. Prof. Dr. Tb.Ronny. R. Nitibaskara; Tegakkan Hukum dengan Hukum; PT. Kompas Media Nusantara; 2006.

3. Ketika Kejahatan Berdulat, Sebuah Pendekatan 
Kriminologi, Hukum dan Sosiologi.

Peradaban : 2001.

4. DR. Made Darma Weda, Kriminologi, PT Raja Grafindo Persada, 1996.

5. Undang - undang : UU No. 13 tahun 2007 Tentang Perlindungan Saksi dan Korban.

6. $\quad$........... UU No. 39 tahun 1999 Tentang Hak Asasi Manusia.

7. Kitab Undang Hukum Acara Pidana ( KUHAP ); 1981.

8. Sari Kampanye Perlindungan Saksi Indonesia; Indonesian Corruption Watch, Mengenal Perlindungan Saksi di Jerman, Jakarta: Indonesian Corruption Watch, 2006.. 